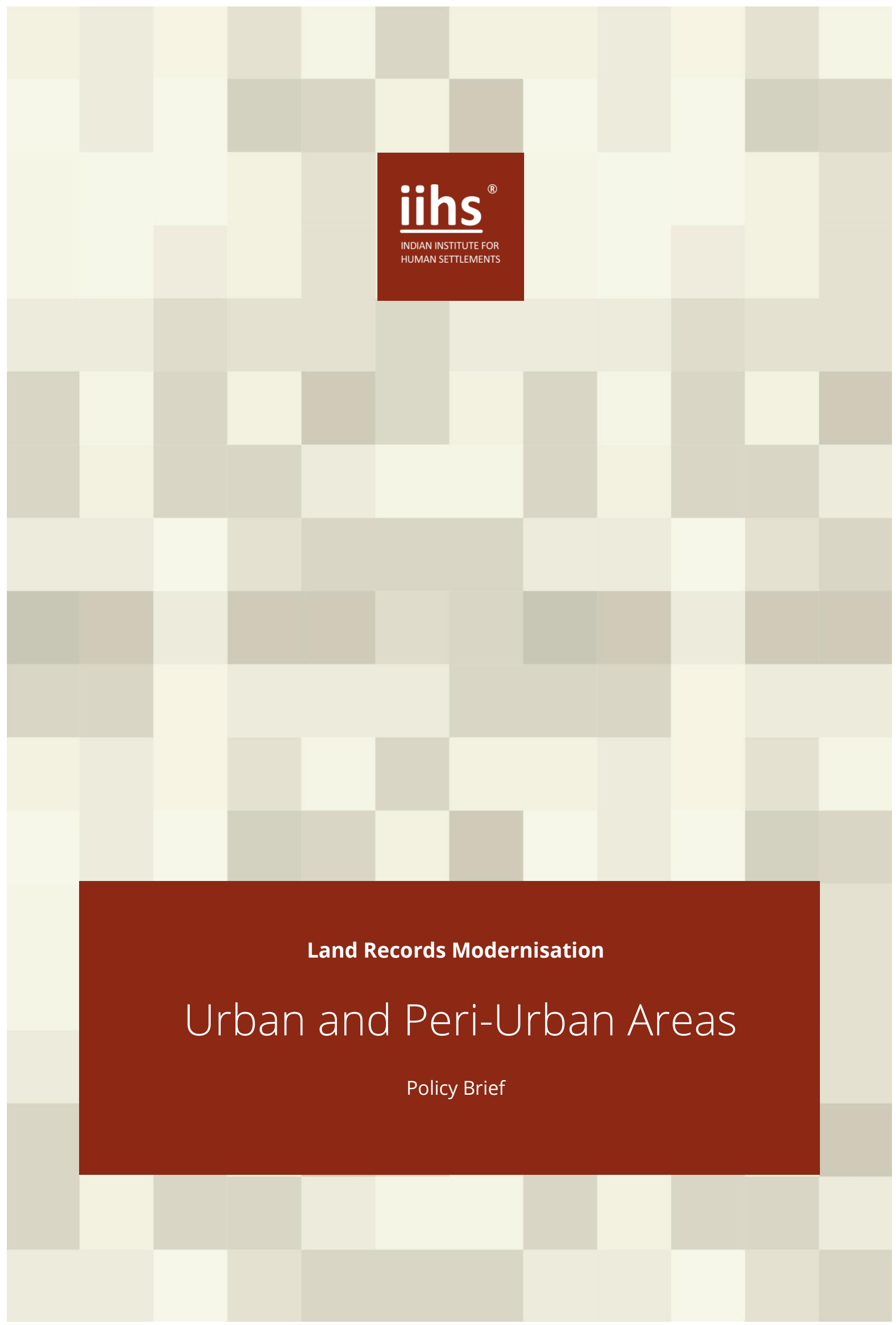




\section{LAND RECORDS MODERNISATION: URBAN AND PERI-URBAN AREAS}

Urban and peri-urban areas are economic hubs and sophisticated land markets. They comprise dense property relationships and accommodate a wide range of socio-economic groups, including ownership rights, tenancy rights, occupancy rights (lease arrangements, rights given under public schemes to residents of informal settlements), development rights (TDRs, other usufruct rights), etc. These property relationships are at the heart of the economic value and GDP, produced in urban areas. The urban informal economy contributes from 40 per cent to 60 per cent of urban GDP and cannot be ignored. Urban property values are also significantly higher than rural values. However, land records, as the name suggests, do not record transactions in the built-up property market. They often do not capture public allotments of land and property and they often inadequately capture inter-governmental issues. Lack of updated and comprehensive urban property records creates incentives for fraud and increases property disputes.

Revenue departments in most states have poor records for urban areas and village settlement areas. These areas were not covered in the colonial records, which focussed on agricultural land, the main source of tax revenues then. Even now, settlement areas of many villages (abadi areas) and cities (which existed in the colonial period) appear as one aggregated revenue estate, with a single survey number in land records, without internal subdivision and ownership details. Post-independence coverage of urban areas has remained incomplete, given high levels of transactions, the high rate of urban spatial expansion and overlapping jurisdictional boundaries of urban authorities. In practice, in most cities, municipal property tax records and registered sale deeds act as proxies to ownership records.

Cities that have some urban records (typically incomplete) fall into the following categories:

\section{Legacy Records:}

a. City Surveys: A few city surveys were conducted in the Bombay and Mysore regions in the colonial period and some urban records exist in these areas. These are restricted to urban areas in Maharashtra, Gujarat and Karnataka (partially), with varying levels of updation or coverage.

b. Integrated Rural and Urban Records: Some states and Union Territories, like Himachal Pradesh, Puducherry, Haryana, etc., do not distinguish between urban and rural areas and therefore have some urban records. Most often, these areas were not urbanised in the colonial period and were 'settled' as agricultural land in the original surveys. These records have been updated as the locations have urbanised and land subdivisions occurred. These urban records usually follow the same RoR format as used in rural areas, even when separate urban formats were specified (e.g., Haryana).

These integrated format of records may or may not cover details of abadi (settlement) areas of the original revenue villages. For example, survey records in Haryana do not map abadi area details, but survey exercises in Bihar did include them. In Himachal Pradesh, regular survey and settlement exercises has enabled coverage of abadi areas for some urban tehsils.

2. New Urban Property Ownership Cards: Some states like Karnataka have initiated a system of urban property ownership cards, with mixed success. Urban Property Ownership Records (UPOR) for example has run into implementation issues. States like Gujarat are trying to upgrade their urban records into a more comprehensive format, using technological initiatives for city surveys.

3. Municipal Property Tax Records: Most cities have municipal tax records, maintained by urban local bodies (ULBs), which enumerate urban properties, but they do not validate ownership and cannot be used in court in case of ownership disputes. The 'khata' system in Bangalore is an example.

\section{Modernisation Initiatives}

The focus of centrally funded records modernisation initiatives is primarily rural. Modernisation 
initiatives are organised under the Digital India Land Records Modernisation Programme (DILRMP; initiated in 2008 as NLRMP), under the central administration of the Department of Land Resources, Rural Development Ministryi.

On-going urban record modernisation initiatives, broadly are of three types (also see Annexe):

1. Urban Property Cards: UPOR in Karnataka and the property cards system in Gujarat and Maharashtra

2. Integrated Systems: Systems in some states such as Haryana (HALRIS and HARIS), Himachal Pradesh (HimRIS and HimBHOOMI) cover some urban areas areas.

3. Municipal Record Upgradation: The Municipal Corporation of Rohtak, Haryana is upgrading its records for municipal purposes in a way that allows incremental development of a cadastral based comprehensive urban property records system.

\section{Challenges of Updating Urban Property Records}

Creating property records for urban areas and building systems for regular and real-time updating is a complex challenge. Cities taking up the challenge have to address the following:

1. Creating a Records Base: Lack of legacy records means a records base for the city needs to be created through (a) comprehensive survey and settlement, (b) voluntary registration and mutation by urban residents, (c) amalgamation of records, being maintained by various urban authorities, including ULBs.

Any or all of these methods would need extensive on-ground verification, to cross-check enumeration of urban properties and verify, (a) ownership or property relationship, (b) possession, keeping in mind the issue of encroachments, (c) spatial extent, (d) property classification, and (e) encumbrances, including pending disputes, mortgages, etc.

2. Record Updating: High quantum of transactions in urban areas creates the imperative for regular and real-time updating. This may mean both individual and institutional level updating, simplification of registration and mutation processes in urban areas, institutional data sharing to capture change in land use, land acquisition, property allotments etc.

3. Jurisdictional Issues: Urban and peri-urban areas have multiple local and state level government bodies, parastatals, government appointed task forces, new authorities for special zones, and new public-private entities that own, dispose and administer land. The Revenue Department has statutory powers to create and maintain records in urban areas. However, in cities, where they have not performed these functions, new initiatives administered by them, may run into log-jams with other authorities that have a longer administrative and political history in the city. Moreover, the Revenue Department cannot access central funds for record modernisation in urban areas.

Main jurisdictional issues, include:

a. Multiple Authorities: Planning and development authorities, ULBs, industrial authorities, etc., have overlapping jurisdictions and there is a lack of good spatial databases highlighting how their boundaries overlap.

b. Area Changes: Jurisdictional areas change frequently, creating overlaps. In Bangalore, the urban development authority, BDA, has statutory powers to sanction property subdivisions, superceding those of the Revenue Department in urban areas. However, these subdivisions may not be updated in revenue records. In Himachal Pradesh, the Revenue Department sanctions subdivisions in urban areas, without consulting the Town and Country Planning Department, despite statutory requirement, which leads to developments without planning permissions that may be demolished by planning authorities.

c. Data 'Silos': Data maintained by different authorities are in 'silos', without institutional data bridges. As such, when large-scale changes in land and property ownership takes 
place through institutional interventions such as land acquisition, new property allotments, etc., they are not automatically updated in the property records. Updating occurs when individuals undertake a mutation process, which is not common in urban areas.

d. Multiplicity of Modernisation Efforts: Each urban authority invests in the latest technologies to create records for their jurisdictional area. Without data-sharing, these efforts may overlap, repeat and even be at cross-purposes to one another, without yielding a property record in the public domain for the city.

4. Change of Land Use: Peri-urban areas are not statutorily demarcated zones, but are transforming rapidly to accommodate groups ranging from low-income migrants to developers and investors. Like transitional zones whose boundaries are in flux, there is lack of clarity about legal and institutional processes associated with development permissions, land amalgamation, land alienation, and maintaining land and property records in peri-urban areas. Speculative interests take advantage of these obscurities, leading to heightened rent-seeking behaviour. No link between property records and permissions being given for Change of Land Use (CLUs) increases opportunities and incentives for property frauds.

5. Comprehensiveness of Records: Records for urban areas are usually the same as the rural RoR format. These formats record land details and noting built-up property details becomes cumbersome. In cities where property cards are being created, there is scope to record details of built-up properties, but the focus is on ownership only. It may be necessary to make urban property records more comprehensive and better suited to the complexity of property relations in urban areas, in terms of properties, rights, transactions and transactional instruments recorded, to reduce property disputes, and create a more effective administration tool for urban areas.

6. Spatial Accuracy: The high value of urban properties puts greater emphasis on spatial accuracy and the need to resolve existing issues and disputes related to encroachments. However, it is important to note than even in countries with indemnified and conclusive titling systems, only ownership is guaranteed and not spatial extent.

7. Financial Considerations: Central funds are not directly available for urban records initiatives. As such, urban initiatives often have to be self-sustaining financially. Fiscal imperatives also raise questions whether the Revenue Department or ULBs should be made responsible for urban property initiatives.

\section{Comprehensiveness of Urban Records and its Updating}

New urban property records need to be based on discernible and replicable protocols to address the complexities of urban property relations, and assess which details need to be included. These complexities if unaddressed would leave large areas of cities not covered by property records, and contribute to further disputes. Some key aspects to be considered include:

1. Spatial Coverage: Urban areas include planned colonies, unplanned but regularised colonies, unplanned and non-regularised colonies, slums and squatter settlements, as well as institutional or industrial estates, under the jurisdiction of different authorities.

2. Types of Properties: This includes built-up properties, air rights, etc., where ownership is separate.

3. Types of Property/Use Rights: This includes properties and use rights (which may overlap in certain areas such as public amenity areas), which have legal, financial and social relevance, including tenurial arrangements, usufruct rights, etc.

4. Types of Transactions/ Transactional Instruments: This includes lease agreements, power of attorney arrangements, mortgages, etc., which clarify encumbrances, mitigate frauds and facilitate credit access. In Indian cities lease markets are more prolific than sale markets. As property prices increase, this trend is likely to become more pronounced. Urban property 
disputes therefore often involve aspects of tenancies and possession. India has one of the most unequal housing markets in the world. A person earning the average national income needs 100 years to afford an 800 sqft house in a city, at the prevailing rates. This is higher than even high value markets like Hong Kong, London, Paris, and Tokyo where it takes between 62 and 67 years (Chakravorty, 2013)ii. Mitigation of fraud in urban property transactions may be effectively addressed by comprehensive urban property records, which include a broader range of tenurial arrangements, including use, possession, and ownership details.

5. Institutional Land Holdings and inter-institutional land transfers

6. Types of Land Classification: Existing categories are mostly rural and there is no data bridge between land classification in urban areas, statutorily defined by planning and development authorities and those that are legally recorded in revenue records. 


\section{ANNEX 6.1: RECENT URBAN INITIATIVES}

\section{Urban Property Ownership Records, Karnataka (Property Card)}

Urban Property Ownership Record (UPOR) is an initiative in Karnataka being implemented in Mysore, Shimoga, Hubli-Dharwad, and Bellary by the Department of Land Revenue. In UPOR, there is a focus on clear presumptive titling, operationalised through a 'quasi-legal' review of ownership claims. Creating UPOR cards involves an extensive resurvey.

UPOR's funding is not via the National Land Records Modernisation Programme. Part of UPOR's funds comes from the Twelfth Finance Commission, under non-plan grants, typically reserved for municipalities. Though the Department of Revenue is not a municipality, it is stated that these property cards will improve municipal revenue collections. UPOR's financing is dependent on private funding from private partners via public-private partnership models. UPOR has not proved to be self-financing yet, especially as the records function (creating, modernising and updating), being modernised by the statelevel revenue and survey departments, remains separate from property tax collections, being collected by the Urban Local Body (ULB).

Mysore's experience with UPOR highlights some implementation issues. Mysore is a relatively planned city with 80 per cent of urban properties developed on sites allotted by the Mysore Urban Development Authority. Under UPOR, more than 300,000 properties were surveyed within nine months and integrated into a spatial database. However, only 180,000 (60 per cent) property owners submitted their documentation for review. Of these, 66,000 applications were rejected for inadequate documentation. As per news reports dated July 2014, only 29,000 (less than 10 per cent) final Property Record (PR) cards and 104,000 (approximately 30 per cent) draft PR cards were issued. Vendor payments are linked to the final PR cards and the experience raises questions about financial incentives for the private sector. The UPOR website states that property data would not be available in a consolidated form. However, given the project costs and project financing status, it remains to be seen if property data is leveraged in any form. UPOR's experience raises questions about financially sustainable formats for modernising property records, in urban areas, where recording and revenue functions are split between different bodies.

The UPOR process does not comprehensively record development and transactional informalities and irregularities, pending property litigations, multiplicity of claims, and focusses on the relatively narrow ambit of clarifying ownership. It is possible that many urban localities (and a significant proportion of property transactions in urban and peri-urban areas) potentially fall outside UPOR's coverage. For example, UPOR surveys are assessing the extent of encroachments on government lands and informing government departments. However, since these areas are irregular, the data is not being incorporated into official property records. UPOR is not being implemented in peri-urban areas. It remains to be seen if courts uphold UPOR's legal due-diligence and 'clear' titles.

\section{City Survey, Gujarat (Property Cards)}

Under the colonial rule, Bombay Presidency had a system of conducting city surveys in settlements with a population higher than 2000 persons. These systems and records of city surveys continue to be applicable in present day Gujarat. Based on primary information collected in 2015, the state has 68 City Survey offices, and each office has around 6-7 surveyors under it. A single municipal corporation may have more than one city survey office located within its limits. These City survey offices issue property cards (PCs) within their respective jurisdictions. As of August 2015, all property cards in the state had been computerised (under the City Survey Information System), with 8 lakh online PCs and another 22 lakh offline PCs.

In the case of Vadodara, in 2014, the City Survey jurisdiction was expanded to 159.9 sq. $\mathrm{km}$ and was made equivalent to the jurisdiction of the Vadodara Municipal Corporation (VMC). As per different sources, the pre-2014 City Survey boundary included only 25\%-32\% of the Non-Agricultural (urban) properties within the Municipal Corporation area. The last extension in the City Survey Jurisdiction, before 2014, took place in 1992 while the boundary has been updated twice (in 2002 \& 2006) since then. 
As per primary sources, the revisions in the City Survey jurisdiction have been slow and independent of the boundaries of other agencies such as VMC or Vadodara Urban Development Authority (VUDA). This suggests a significant lag in the process of updating the City Survey jurisdiction.

In response to the increased jurisdiction of city survey, the Survey and Settlement Department initiated City Survey using Modern technology in the cities of Vadodara and Bhavnagar on a pilot basis. These city surveys would cover the area between the old city-survey jurisdiction, and the new extended jurisdiction. Records of these areas were maintained in the rural ROR format (Village Forms 7 and 12 in the case of Gujarat), and after city survey, would be changed into a property card format, more suited to current characteristics of urban areas. The Survey and Settlement Department also plans to include vertical properties (i.e. apartments) in the property card details, including a recording of the shared undivided interest in the land underneath the apartments.

The survey process itself consisted of four broad stages:

i. Pre-Survey Activities - Establishment of a ground control network, composing the old land records to identify the areas to be surveyed, creation of base maps for survey, awareness measures to inform the general public about the City Survey operations, and intimation to property owners regarding time and date for City Survey on their property

ii. Survey Activities - Conducting on-ground survey including measurements, and collection of documents from the landholders

iii. Post - Survey Activities - Data entry for survey findings (including any objections, disputes, encroachments, etc.), enquiry process (hak choksi) by the City Survey department, a public hearing, and a re-measurement of some plots if required

iv. Promulgation of Records - issuing the new Property Cards and Sanads

The Pre-survey, Survey and Post-survey activities would be conducted by the private vendor, supervised by the City Survey department, while the Hak Choksi (enquiry Process), public hearing and promulgation of property records would be done by the Revenue Department (City Survey Department).

Gujarat is among the very few states which have recently taken up such an initiative to record urban properties in much greater detail. Primary sources report that there are on ground issues in Vadodara about determining the quantum of properties and lands that need to be surveyed, and a lack of protocols which clarify on the detailed processes. However, the state's initiative of building on its legal and institutional legacy of conducting surveys in urban areas, and taking it a step forward by using modern survey methods, is noteworthy

\section{Rohtak Municipal Initiative (Upgraded Records)}

In Haryana, the Rohtak Municipal Corporation (MC) has taken a lead in various technology-based initiatives, to update and modernise urban land and property records. The three key initiatives that the $\mathrm{MC}$ is implementing, eventually to arrive at a 'master record', which would then act as a comprehensive administrative database/system for the municipal area, include:

a. A cadastral mapping initiative,

b. A house numbering exercise, and

c. An initiative to 'regularise' unauthorised colonies.

The Rohtak Municipal Corporation, is primarily interested in making municipal tax collections more efficient. The initiatives in Rohtak town could incrementally feed into the Land Record Management system focusing on urban areas, for the following reasons:

1. A first-level mapping of residential colonies in the peri-urban areas of Rohtak town is being undertaken, which is pioneering in the Indian context, where peri-urban areas are represented in master plans, but without mapping the existing situation/land holdings. The current initiatives are not producing geo-referenced accuracy with regards to individual property boundaries.

2. An enumeration of urban properties, including built-up area details and details of the number of floors in urban properties is being undertaken. These details are typically part of a municipal tax record. However, if this database is incrementally developed into a system of urban property 
records, it could add greater detail and granularity to urban property records as compared to revenue records that currently exist for urban areas. The house numbering exercise is being used to generate a unique property ID, which would be eventually integrated with the mapping exercise database.

3. A cadastral link is being created between the revenue estates marked in the revenue records and colony boundaries and individual properties being surveyed now, which fall within these estates. The cadastral link in the proposed database geo-references boundary details of revenue estates and geo-tags individual properties, within these estates. This offers a potential preliminary base for developing a comprehensive and legally relevant urban property records in time.

It is not clear whether the new spatial details have legal sanctity (such that courts will hold up property delineations in the database, in the event of disputes), especially since the methodology being used does not incorporate a rigorous on-ground verification of possession, ownership and extent. This is also a matter of generating appropriate on-ground authentic verifiable traction for the courts to also uphold the new data.

Key gaps where the present initiatives do not reflect urban property details comprehensively (i.e., on ownership, possession, extent, classification and encumbrances) include the need for clear protocols for greater accuracy, the need to extend to the town's core areas and HUDA areas, and the need for clear updating processes in real time.

Current initiatives are not yet creating ownership-based urban property records or mitigating recordsrelated urban property disputes. However, there are certain processes and components that are currently being adopted that highlight the potential to scale up existing initiatives towards the development of an urban property records system that is legally sound and commensurate with the Revenue Department's records. These processes include the updating of revenue records through onground surveys of properties and surveys of new urban layouts. The components of the database being created involve cadastral mapping and procedures to arbitrate claims and objections from the public.

\section{Himachal Pradesh (Integrated System)}

Unlike many states, Himachal Pradesh (HP) has land records for urban areas as well. The entire state is divided into revenue estates or mohals, which fall under the jurisdiction of local revenue officials like patwaris and kanungos. A revenue estate might be part of a rural jurisdiction (village panchayats), or part of an urban jurisdiction (municipal area or planning area) or might have rural/urban/periurban character, irrespective of which jurisdiction it falls under. There is no difference in the processes (registration, mutation, settlement), functionaries (patwari, kanungo, tahsildar), or record formats (jamabandi, mussavi, misal haqiyat) between these urban and rural areas. However similar to other states, there is ambiguity regarding changing planning/development/municipal jurisdictions, in urban and peri-urban areas, and there exists some disconnect between revenue jurisdictions and other designated areas.

A distinct feature of urban land records in HP is the entry of built-up areas in the 'remarks' column of the jamabandi. These are also updated with every transaction of built-up areas. Attempts are being made to integrate records of development authorities such as HIMUDA with the existing land records, but more detailed protocols might be needed.

Settlement operations are another reason why urban records in HP are more updated than other states. Often during the course of settlement in urban areas, properties in abadi areas (which were earlier clubbed in a single khasra number) are individually re-measured and recorded. Similarly, plots, which have undergone partition are marked in the maps. However, settlement operations are conducted only every 40 years, and often take a long time to complete. There is no standardisation in the level of details within the state, or even within a district. Revenue estates which have undergone revised settlement in last ten years are relatively more detailed than the ones settled 20-30 years ago. 
The urban and peri-urban governance system in Himachal is also noteworthy because of the presence of revenue officials across urban institutions such as municipalities, planning authorities, development authorities, industrial development authorities, etc. Before any land is notified as their jurisdiction by these organisations, or before it is acquired for development, the revenue officials in these organisations link revenue records and maps to the organisation's functions and databases. Thus, an administrative link and a database link already exist, which need to be built upon.

\section{Bihar (Upgraded Records in an Integrated System)}

Similar to Himachal Pradesh, the land records system in Bihar also does not distinguish between urban and rural areas. Entire state is divided into revenue villages called mauzas, which might or might not be part of planning and municipal boundaries. During settlement, urban maps are created at a larger scale than rural maps, and individual plots in abadi areas are also measured. Revenue is collected from all land owners, based on their usage of land, for agricultural, residential or commercial purposes.

A distinctive feature of Bihar is the creation of a property holding in the municipal records. The urban local bodies reserve the right to collect taxes from built up properties, by creating a 'holding' in the name of owner. This creation of a holding can be challenged and rectified through a quasi-judicial process, within the municipal organisation, similar to a title-case in revenue courts. This feature of urban property records in Bihar assumes significance in the light of new property tax mapping exercises which have recently been concluded in the towns of Katihar and Purnea, and are proposed for several other urban centres. These mapping exercises are more detailed than the earlier property records, and create detailed maps of the properties within municipal boundaries.

\section{ANNEXE 6.2: REAL ESTATE MARKETS AND ACCESS ISSUES IN URBAN AND PERI-URBAN AREAS}

\section{High Growth but Unequal Urban Property Markets}

The Indian real estate sector is one of the fastest growing markets in the world (CCI, 2013; IBEF 2014) ${ }^{\mathrm{iii}}$, attracting "...foreign developers, property investment companies and real estate investment trusts, banks, private equity firms and hedge funds" (Searle, 2013) iv, and 'informal funds' set up by non-resident Indians with an investment range of US\$10-25 million (Ramanathan, 2007 as quoted in Searle, 2013)v. By 2020, the real estate sector is estimated to grow to US $\$ 180$ billion (IBEF, 2014) ${ }^{\text {vi }}$. The sector's growth potential and profile of investors, has renewed interest in land records and 'clear' titles, across India.

However, this high value real estate market is spatially concentrated and Tier-I cities account for 40 per cent of the expected growth (IBEF, 2014) vii. Peri-urban areas, where land consolidation is possible, attracts much of the attention. Indian developers, partnering foreign investors, often negotiate returns of 100-150 per cent for consolidating land and making it free of legal disputes and encumbrances. Foreign investors/funds are promised 20-25 per cent returns (Searle, 2013) viii, considered low, since India is perceived as a high-risk destination.

Urban property markets in India are one of the most unequal in the world. On one end, a segment of the market (described above) has become a fungible asset, yielding globally competitive returns. At the same time, nearly 50 per cent of urban residents access urban land through tenurial arrangements that fall within the spectrum of informality and partial formality. Even within the formal housing market, 'access' is a significant issue. Studies quantify that a person earning the national average income can afford to buy an $800 \mathrm{sft}$. house at prevailing rates in 100 years, as compared to 62-67 years in case of other inflated housing markets such as Hong Kong, London, Paris and Tokyo (Chakravorty, 2013) ${ }^{\mathrm{ix}}$.

Only a limited proportion of India's population can access the sales market and rental markets are significant from an 'access' perspective. Meanwhile, sales market in India are also characterised by the growing presence of 'land banks', amongst domestic real estate developers and corporates, interested in land as an asset class because of its stability and its guaranteed returns above prevalent rates of inflation. This acts as a barrier against land being distributed amongst more productive users. 
A CBDT (2012) $\times$ report also estimates that over 40 per cent of undisclosed incomes in India (also called the 'black' economy - an underground economy, which has emerged to avoid taxation) are parked in real estate. It is estimated that a large proportion of the 'black' money sent out of the country, is siphoned back as investment via tax havens such as Mauritius. 38 per cent of India's FDI was routed through Mauritius between 2000 and 2012 (Sharma, 2014) ${ }^{x i}$ as compared to 6 per cent from the US.

\section{Impact on Property Records and Titling}

The current realities of how urban property markets in India are structured and how these structures are affecting transactional practices are of significance for creating comprehensive urban property records. Yet the focus of new urban initiatives, such as UPOR in Karnataka fare relatively limited. UPOR focuses on ownership and does not capture rental market transactions. Also, the implications of advocating conclusive titling need to be analysed in light of the above issues, especially with regard to an incremental phasing strategy. Moreover, more detailed analyses of the issues and concerns affecting land and property markets and populations beyond high growth (and speculative) real estate market needs to be undertaken, before determining the appropriateness and relevance of conclusive titling.

The lack of titles is often linked to reduced access to formal, institutional credit and opportunities available to the poor to join formal markets (De Soto, 2000)xii. However, property titling is often not sufficient in itself to improve access to formal markets (Payne, Lasserve and Rakodi, 2009xiii; Gilbert, $2002^{x i v}$ ). Households need to have the capacity to service loans in order to take advantage of formal credit lines (UN- Habitat, 2008) ${ }^{\mathrm{xv}}$. Similar to loan classes that emerged in the US, when sub-prime loans were made mainstream, ad-hoc government property titling could engender a prime and sub-prime class structure in India's housing finance markets. Significant scaling up of institutional capacities is needed to allow people engaged in informal networks to transition to formal markets. Views prioritising the reduction of vulnerability, highlight that the diversity of needs, capacities and life conditions of vulnerable and marginalised populations requires a nuanced and incremental approach acknowledging a broad continuum of rights to land and property, premised on security of tenure, defined as protection against the vulnerability of eviction, rather than a strict emphasis on legal property titles (UN Habitat, 2008) ${ }^{\mathrm{xvi}}$. 


\section{ANNEXE 6.3: URBAN INSTITUTIONAL JURISDICTIONS \& DESIGNATED AREAS}

Overlapping and expanding jurisdictions: case study Rohtak town, Haryana

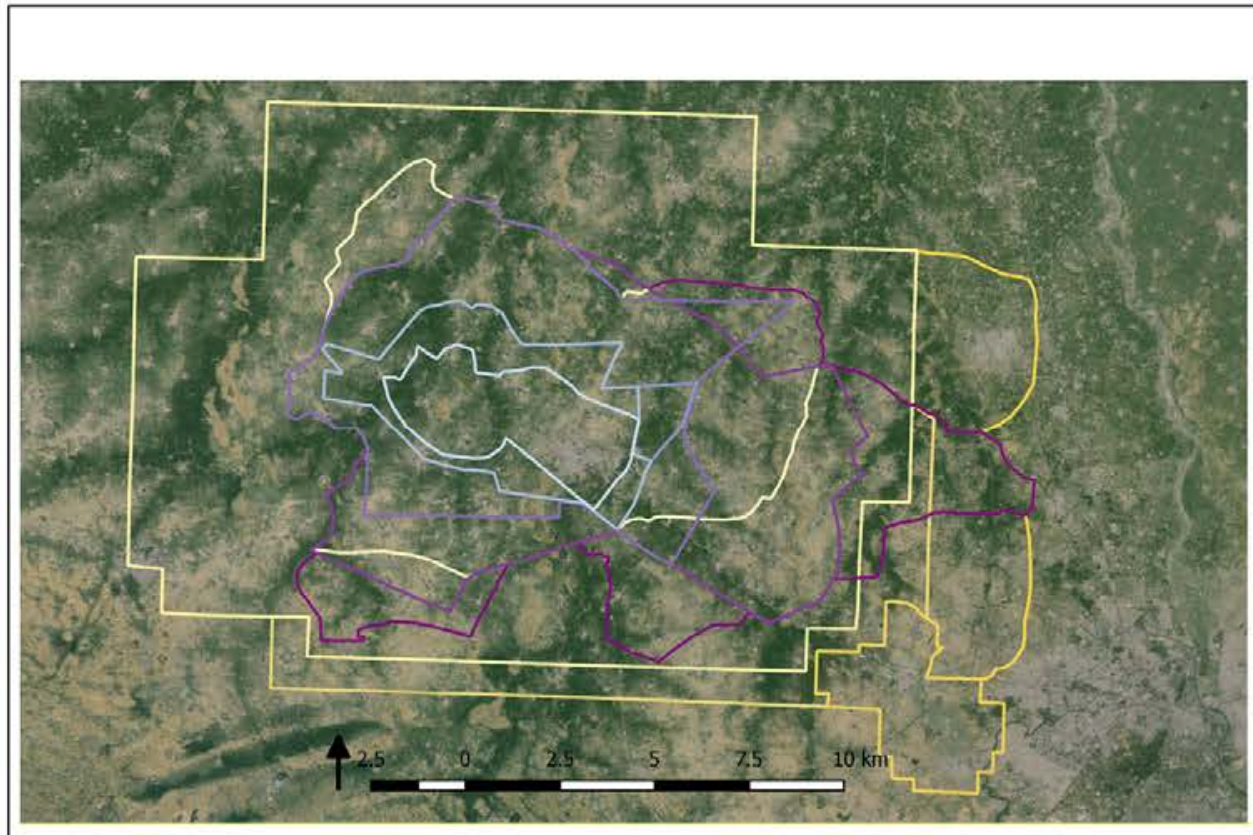

- Rohtak Municipal Corporation collects property taxes wthin its jurisdiction. It is also under this jurisdcition that the exercises studied in this report (Mapping, house numbering, regularisation) are being carried out.

DTCP delineates Controlled Areas, thereby freezing their land use, unless a Change of Land Use permission is granted. Controlled areas are generally of two types - around municipal boundaries, or around activity nodes such as temples, hospitals, colleges etc where development is anticipated. Owing to expansion of municipal boundaries, many controlled areas have now come under jurisdiction of MC, which grants CLU permissions for them.

- DTCP also prepares the development plan for each city, hence delineating the development area boundary. Any colonies which come up wthin this development area, or within the controlled area, must obtain a license from DTCP. Colony Licenses within development arealn Rohtak, Controlled Area boundaries are based on khasra numbers (since 1996), but RoRs of thses khasra numbers do not indicate whether they are part of controlled areas

- Changing jurisdictions of these authorities increases the complexity of urban institutional framework, and can lead to ambiguity in the development processes.
1971
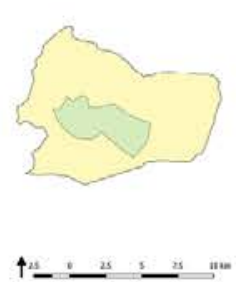

2006

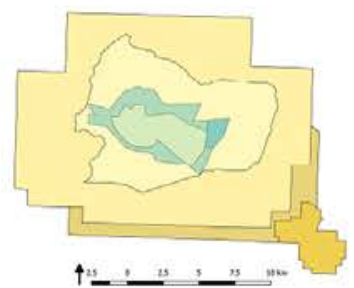

2010

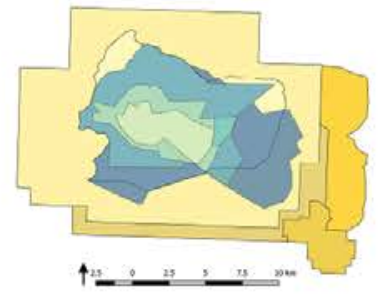

Legend

Rohtak MC Jurisdiction

Old Municipal Committee Boundary (pre 1971) - Extended Municipal Committee Boundary (1991)

New Extended Municipal Coundil Boundary (2001)

Municipal Council Boundary (2007)

Extended Municipal Corporation boundary (20
New Municipal Corporation Boundary (2012)

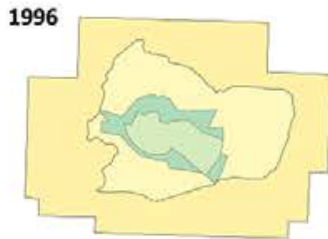

$4^{24}-2^{35} 3^{5}$

2007

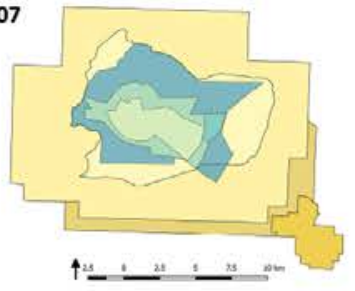

2011

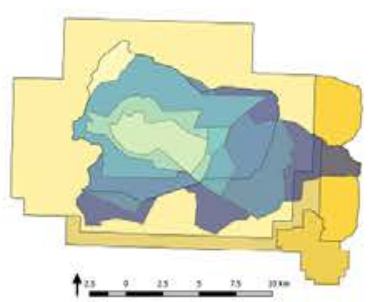

Source: Municipal boundaries (1971, 1991, 2010 and 2012) from Rohtak Development Plan 2031, Dept. of Town \& Country Planning (http://tcpharyana.gov.in/DevelopmentPlan/DDP\%20Rohtak-2031\%20AD.pdf ), Municipal boundaries (2001, 2007) and year of municipal boundary notifications from Singh \& Kumar, 2012 (Singh, N., Kumar, J., 2012, Urban Growth and Its Impact on Cityscape: A Geospatial Analysis of Rohtak City, India, Journal of Geographic Information System, 2012, 4, 12-19,

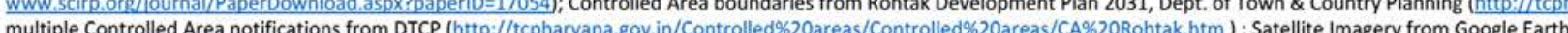


Typology of 'designated areas' in an urban area: case study Rohtak town, Haryana

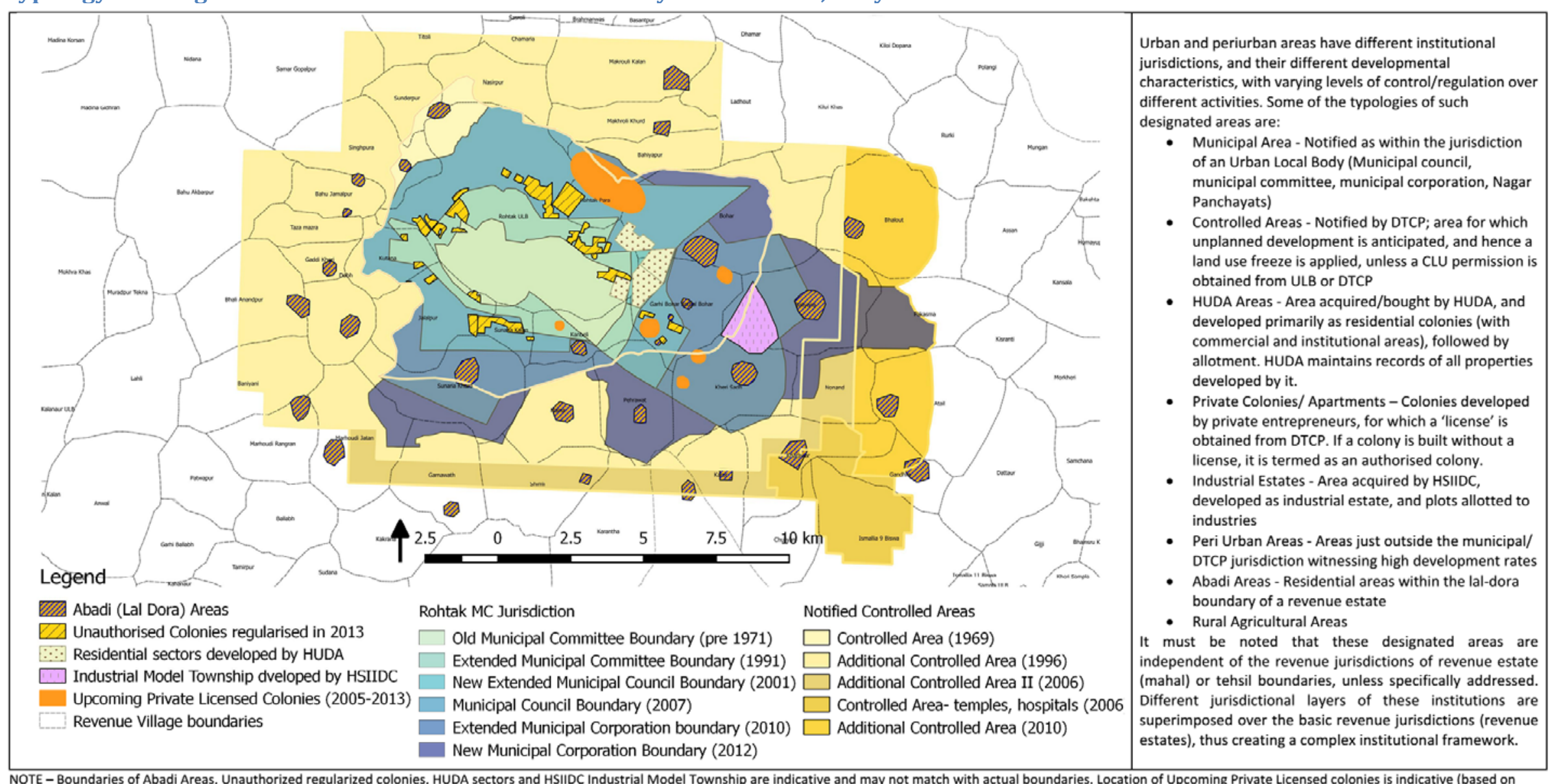
location of sector). These are only the licenses granted, actual development has not taken place in several colonies

Source: Municipal boundaries (1971, 1991, 2010 and 2012) from Rohtak Development Plan 2031, Dept. of Town \& Country Planning (http://tcpharvana.gov.in/DevelopmentPlan/DDP\%20Rohtak-2031\%20AD.pdf ), Municipal boundaries (2001, 2007) and year of municipal boundary notifications from Singh \& Kumar, 2012 (Singh, N., Kumar, J., 2012, Urban Growth and Its Impact on Cityscape: A Geospatial Analysis of Rohtak City, India, Journal of Geographic Information System, 2012, 4, 12-19,

www.scirpor multiple Controlled Area notifications from DTCP (htttp://tcpharvana.gov.in/Controlled\%20areas/Controlled\%20areas/CA\%20Rohtak.htm ); Revenue Village boundaries from District website (http://rohtak,nic.in/images/map.jpg)

Abadi Areas from Rohtak Development Plan 2031, Dept. of Town \& Country Planning (http://tcpharyana.gov.in/DevelopmentPlan/DDP\%20Rohtak-2031\%20AD.pdf) using Satellite imagery from Google Earth; Regularised unauthorized colonies from Rohtak

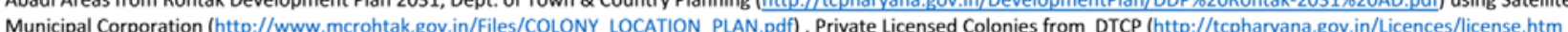




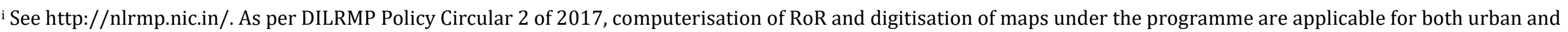
rural areas. However, DILRMP does not go beyond land and details of immovable property are not computerised/ digitised under the programme.

ii Chakravorty, S. (2013). The price of land: acquisition, conflict, consequence. Oxford University Press.

"Corporate Catalyst India (2013). A Brief Report on Real Estate Sector in India. New Delhi: CCI ; IBEF (2014) Real Estate in India. Retrieved from: http://www.ibef.org/industry/real-estate-india.aspx

iv Searle, L. G. (2013). Conflict and commensuration: contested market making in India's private real estate development sector. International Journal of Urban and Regional Research, 38(1), 60-78

$\checkmark$ ibid

vi IBEF (2014) Real Estate in India. Retrieved from: http://www.ibef.org/industry/real-estate-india.aspx

vii ibid

viii ibid

ix Chakravorty, S. (2013). The price of land: acquisition, conflict, consequence. Oxford University Press.

x CBDT. 2012. White Paper on Black Money. Accessed at http://finmin.nic.in/reports/WhitePaper_BackMoney2012.pdf

xi Retrieved from http://scroll.in/article/666658/India's-land,-and-not-Switzerland,-is-where-the-hunt-for-

black-money-should-begin

xii De Soto, H. (2000). The Mystery of Capital: Why Capitalism Triumphs in the West and Fails Everywhere else New York: Basic Books

xiii Payne, G., Durand - Lasserve, A., \& Rakodi, C. (2009). The limits of land titling and home ownership. Environment and urbanization, 21(2), 443 - 462

xiv Gilbert, A. (2002). On the mystery of capital and the myths of Hernando de Soto: What difference does legal title make?, International Development Planning Review, 24(1), 1-19

xv UN-HABITAT, (2008). Secure land rights for all. Nairobi, Kenya, United Nations Human Settlements Programme: $40 \mathrm{p}$

xvi UN - HABITAT, (2008). Secure land rights for all. Nairobi, Kenya, United Nations Human Settlements Programme 